\title{
Differences in Serum Magnesium Levels in Diabetic and Non-Diabetic Patients Following One-Anastomosis Gastric Bypass
}

Eva Winzer ${ }^{1}{ }^{(}$, Igor Grabovac ${ }^{1, *} \mathbb{0}$, Bernhard Ludvik ${ }^{2}$, Renate Kruschitz ${ }^{3,4}$, Karin Schindler $^{4}$, Gerhard Prager ${ }^{5}$, Carmen Klammer ${ }^{4,6}$, Lee Smith ${ }^{7}$, Friedrich Hoppichler ${ }^{8,9}$, Rodrig Marculescu $10 @$ and Maria Wakolbinger ${ }^{1,4,8}$

1 Department of Social and Preventive Medicine, Centre for Public Health, Medical University of Vienna, Spitalgasse 23, 1090 Vienna, Austria

2 Department of Medicine 1 and Karl Landsteiner Institute for Obesity and Metabolic Disorders, Rudolfstiftung Hospital, Juchgasse 25, 1030 Vienna, Austria

3 Division of Internal Medicine, General Public Hospital of the Order of Saint Elisabeth, Völkermarkter Straße 15-19, 9020 Klagenfurt, Austria

4 Division of Endocrinology and Metabolism, Department of Internal Medicine III, Medical University of Vienna, Spitalgasse 23, 1090 Vienna, Austria

5 Division of General Surgery, Department of Surgery, Medical University of Vienna, Spitalgasse 23, 1090 Vienna, Austria

6 Department of Internal Medicine, Convent of the Brothers of Saint John of God, Seilerstätte 2, 4021 Linz, Austria

7 Cambridge Centre for Sport and Exercise Sciences, Anglia Ruskin University, Cambridge CB1 1PT, UK

8 Special Institute for Preventive Cardiology and Nutrition-SIPCAN, Rabenfleckweg 8, 5061 Salzburg, Austria

9 Division of Internal Medicine, Krankenhaus der Barmherzigen Brüder, Kajetanerplatz 1, 5010 Salzburg, Austria

10 Clinical Institute for Medical and Chemical Laboratory Diagnostics, Department of Laboratory Medicine, Medical University of Vienna, Spitalgasse 23, 1090 Vienna, Austria

* Correspondence: igor.grabovac@meduniwien.ac.at; Tel.: +43-1-40160-34895

Received: 19 July 2019; Accepted: 19 August 2019; Published: 22 August 2019

check for updates

\begin{abstract}
Patients with obesity and type 2 diabetes mellitus (T2DM) are regarded to have reduced serum magnesium $(\mathrm{Mg})$ concentrations. We aimed to assess the changes in serum $\mathrm{Mg}$ concentrations at 12-month follow-up in patients, with and without T2DM, who underwent one anastomosis gastric bypass surgery. Overall, 50 patients ( $80 \%$ female, age 42.2 (12.5) years) with morbid obesity (mean baseline BMI $43.8(4.3) \mathrm{kg} / \mathrm{m}^{2}$ ) were included in the analysis. Half of the included patients had T2DM diagnosed at baseline, and these patients showed lower serum $\mathrm{Mg}$ concentration $(0.78(0.07))$ vs. 0.83 $(0.05) \mathrm{mmol} / \mathrm{L} ; p=0.006)$, higher blood glucose levels (129.9 (41.3) vs. $87.6(8.1) \mathrm{mg} / \mathrm{dL} ; p<0.001)$ as well as HbA1c concentrations (6.7 (1.4) vs. $5.3(0.5) \% ; p<0.001)$. During follow-up, BMI and glucose levels showed a decrease; however, serum $\mathrm{Mg}$ levels remained stable. At baseline $42 \%$ of patients were found to be $\mathrm{Mg}$ deficient, which was reduced to $33 \%$ at six months and to $30 \%$ at 12 months follow-up. Moreover, patients with T2DM had an odds ratio of $9.5(95 \% \mathrm{CI}=3.0-29.7 ; p<0.001)$ for magnesium deficiency when compared to patients without T2DM. Further research into the role of $\mathrm{Mg}$ and its role in T2DM and other obesity-related comorbidities are needed.
\end{abstract}

Keywords: serum magnesium; obesity; type 2 diabetes mellitus; one anastomosis gastric bypass 


\section{Introduction}

Magnesium (Mg) is the second most abundant intracellular electrolyte serving as a co-factor in over 300 different enzymatic and biochemical reactions responsible for normal functioning of the organism [1-3]. It is also involved in blood glucose control, given its vital role in activating the beta-subunit of the insulin receptors [4]. However, taking into account the multitude of processes in which $\mathrm{Mg}$ is involved with, the physiological homeostasis of $\mathrm{Mg}$ is still not well understood [4,5].

$\mathrm{Mg}$ is present in both animal and plant based foods, with legumes, nuts, grains, seeds, and green leafy vegetables presenting the richest sources [6]. However, even with the relatively broad distribution of foods containing $\mathrm{Mg}$, studies have indicated that intake of $\mathrm{Mg}$ is suboptimal, i.e., not reaching the recommended daily intake [7]. An analysis of nationally representative data from the United States showed that more than $80 \%$ of Americans do not meet the recommended daily intake with older African Americans showing the lowest Mg intake compared to other ethnic groups [8].

Reduced serum Mg (hypomagnesemia) has also been reported in patients with obesity, diabetes, and hypertension, and has been suggested as a biomarker for the symptoms cascade leading to the metabolic syndrome $[9,10]$. Studies reported that men with low serum Mg values had a two-fold increase in the incidence of type 2 diabetes mellitus (T2DM), while those in the highest quintile of $\mathrm{Mg}$ intake can reduce their diabetes risk by more than $30 \%$. The exact mechanism by which hypomagnesemia induces or worsens T2DM is unclear, however, both secretion and action of insulin seem to be affected [11]. A possible mechanism could be the decreased renal $\mathrm{Mg}$ reabsorption as a consequence of insulin deficiency [11] or concomitant use of medications such as proton pump inhibitors, diuretics, statins, and antimicrobial agents [12].

The increasing disease burden of obesity and the increase in its worldwide prevalence presents a major public health issue [13]. The Austrian Health Interview Survey (AT-HIS) in 2014 included adults from a representative sample of the Austrian population. Overall, 15,771 individuals were interviewed and $56 \%$ were female. In this sample, $33 \%$ of the adults were overweighed (male $40 \%$, female $26 \%$ ) and $14 \%$ were obese (male 16\%, female 13\%) [14]. Consecutively, lasting therapeutic effects can only be achieved through weight loss, as it is associated with improved metabolic function as well as decrease in risk of comorbidities $[15,16]$. Weight loss can be achieved through various lifestyle interventions, such as increasing physical activity levels and controlling caloric intake. However, in morbidly obese patients bariatric surgery is preferred since it is associated with long term weight loss and reduced prevalence of comorbidities [17]. According to the 4th Global Registry Report of the International Federation for the Surgery of Obesity and Metabolic Disorders (IFSO) from 2018, 1255 bariatric surgeries have been reported in Austria between 2014-2018, and more than third preformed were the one anastomosis gastric bypass and mini-gastric bypass, making them a group of most commonly done bariatric surgeries in Austria [18].

Studies on obese patients following weight loss have reported inconsistent results, with some finding improvements in serum $\mathrm{Mg}$ levels and some reporting no changes in diabetic and non-diabetic patients with obesity $[5,19,20]$. As Mg has been linked to a myriad of positive health outcomes [21], and in light of rising trends in global obesity prevalence, our study aimed to investigate changes in serum $\mathrm{Mg}$ levels in patients with and without diabetes mellitus who underwent one-anastomosis gastric bypass (OAGB) before and after a 12-month follow-up. To our knowledge, this is the first study looking into $\mathrm{Mg}$ serum concentration of a patient cohort after this type of bariatric surgery.

\section{Materials and Methods}

\subsection{Study Design}

This study is a secondary analysis of the data and blood samples of participants who had been enrolled in the LOAD-study ("Link between Obesity And Vitamin D"), a six-months double-blind, placebo-controlled, randomized trial of vitamin D supplementation. The primary aim of the LOAD-study was to examine the efficacy and safety of a forced vitamin D regimen versus conventional 
supplementation on parameters of vitamin D metabolism in morbidly obese, vitamin D-deficient patients undergoing OAGB [22]. Inclusion criteria were; planned one-anastomosis gastric bypass (OAGB) surgery, above 18 years old, 25-hydroxy-vitamin D (25(OH)D) serum concentrations of below $75 \mathrm{nmol} / \mathrm{L}$, no vitamin D supplementation, and a body weight below $140 \mathrm{~kg}$ (due to body weight limitation of the dual energy $X$-ray absorptiometry). Specific exclusion criteria included any other planned form of bariatric surgery than OAGB, hypo- and hypercalcemia, renal insufficiency, or primary hyperparathyroidism. In the first six months after OAGB surgery, the intervention group received the following vitamin D dosing regimen: Up to three oral loading doses of each 100,000 IU in the first month postoperatively, followed by maintenance dose of 3420 IU/day; and the control group received conventional supplementation (placebo in the first month with following maintenance doses of 3420 IU/day). Afterwards, both groups were recommended to continue the vitamin $\mathrm{D}_{3}$ supplementation until the follow-up visit at 12 months. The details on design, the used materials and methods, as well as the sample size calculation of the LOAD-study, have been previously published [23]. Primary analysis included the repeated-measures analysis of covariance (ANCOVA) using random error (linear mixed model) to assess the effects of time and the interaction for changes in parameters between the groups by using different covariance structure models as appropriate, and were adjusted for age, sex, and baseline values.

All OAGB procedures were performed at the General Hospital Vienna, Medical University of Vienna by the same surgical team using a laparoscopic approach. It is a simplified procedure that consists of a unique gastrojejunal anastomosis between a 30 to $40 \mathrm{~mL}$ sleeve gastric pouch and a jejunal omega-loop of approximately $200 \mathrm{~cm}$ [24]. The study methods are in accordance with the CONSORT (Consolidated Standards Of Reporting Trials) guidelines for reporting randomized trials [25].

This study was approved by the local Ethics Committee of the Medical University of Vienna ( $\mathrm{No}^{\circ}$ 1899/2013), by the Austrian Competent Authority (No ${ }^{\circ}$ LCM-718280-0001), registered at clinicaltrials.gov (Identifier: NCT02092376) and EudraCT (Identifier: 2013-003546-16), complies with the Declaration of Helsinki [26], and conducted from April 2014 to June 2016 at the Medical University of Vienna. The study participants were scheduled for OAGB surgery and all of them gave written informed consent preoperatively.

\subsection{Assessment of Variables}

Data were assessed before surgery (T0), at 6 months (T6), and at 12 months postoperatively (T12). At T0, age, sex, and medical history (e.g., comorbidities, prescribed medication) were collected as previously described [23]. Height and body weight (measured with the calibrated scale seca mBCA 515) were obtained for each participant at the three time points.

Blood samples were collected and serum $\mathrm{Mg}$, glucose, $\mathrm{HbA}_{1 \mathrm{c}}$, triglycerides, total cholesterol, $\mathrm{HDL}$ cholesterol, and LDL cholesterol were used for this secondary analysis.

\subsection{Statistical Analysis}

The results are expressed as mean (standard deviation) for continuous and as percentages for categorical variables. In order to test for normal distribution, a visual test (histograms and box plots) was used and the Kolmogorov-Smirnov test was applied in addition.

At baseline the difference between diabetic patients and parameters such as sex, age, BMI, glucose, $\mathrm{HbA}_{1 \mathrm{c}}$, oral antidiabetic drugs (OAD) and insulin use, serum lipid levels such as triglycerides, total cholesterol, HDL cholesterol, cholesterol/HDL ratio, and LDL cholesterol was assessed with $t$-test and $\mathrm{Chi}^{2}$-test. The statistical association between serum $\mathrm{Mg}$ and parameters such as diabetes mellitus, glucose, $\mathrm{HbA1c}$, and serum lipid levels was examined by Pearson correlation coefficients.

The main outcome of interest was the change in serum $\mathrm{Mg}$ concentration in the first postoperative year. Moreover, the changes in BMI, blood sugar levels, and serum lipid levels were also assessed. We used the entire sample for this analysis. We applied repeated-measures analysis of covariance (ANCOVA) using random error (linear mixed model) to assess the effect of time by using different 
covariance structure models as appropriate and which were adjusted for age, sex, and baseline values to supply an unbiased estimate of the mean difference [27]. A post hoc analysis with Bonferroni correction was used.

Estimates of the prevalence of $\mathrm{Mg}$ deficiency over time were calculated using generalized estimating equation (GEE) with a logit link function for binary outcomes and unstructured covariance matrices. With this approach, we examined effects with time as repeated factor with Mg deficiency as dependent variable, adjusted for age and sex.

Means were compared unadjusted without imputation of missing data. All statistical analyses were performed with IBM ${ }^{\circledR}$ SPSS ${ }^{\circledR}$ Statistics for Windows, Version 23 software (IBM Corporation, Armonk, NY, USA). $p$-values $<0.05$ were considered statistically significant and all tests were two-sided.

\section{Results}

\subsection{Patients' Characteristics}

Out of 67 eligible patients, 17 declined to participate (25\%). The remaining 50 patients entered the randomized controlled trial [22]. Baseline characteristics are demonstrated in Table 1. Fifty percent of the patients suffered from type 2 diabetes mellitus (T2DM) and $22 \%$ of the patients used statins or fibrates. Diabetic patients and patients using statins/fibrates were significantly older. Two-thirds of the diabetic patients and over $90 \%$ of patients using statins/fibrates had an $\mathrm{Mg}$ deficiency. Serum lipid levels were not significant between diabetic and non-diabetic patients.

There was a statistically significant association between serum Mg and T2DM $(\mathrm{r}=-0.38, p=0.006)$, glucose $(\mathrm{r}=-0.42, p=0.002), \mathrm{HbA}_{1 \mathrm{c}}(\mathrm{r}=-0.52, p<0.001)$ and statin/fibrate use $(\mathrm{r}=-0.48, p<0.001)$. There was no statistically significant association between serum $\mathrm{Mg}$ and serum lipid levels.

3.2. Associations between Diabetic Patients and Serum Magnesium, Blood Glucose and Serum Lipid Parameters in the First Postoperative Year

As this study is a secondary analysis of the LOAD-study, a post hoc power calculation was applied for the main outcome (change in serum Mg concentration). This power analysis showed that the current study had a power of $83 \%(\alpha=0.05)$ to detect differences in the mean serum Mg concentration between non-diabetics $(n=25)$ and diabetics $(n=25)$ after 12 months.

Table 2 shows the comparison between diabetic and non-diabetic patients on BMI, serum $\mathrm{Mg}$, blood glucose, and serum lipid values over time. At T0, diabetic patients showed significantly lower serum $\mathrm{Mg}$, and higher glucose and $\mathrm{HbA}_{1 \mathrm{c}}$ concentrations. At $\mathrm{T} 12$, significant group differences in $\mathrm{BMI}$ and glucose values could be found. There were also between group differences in serum $\mathrm{Mg}$ concentration at $\mathrm{T} 6$ and at $\mathrm{T} 12$. In addition, $\mathrm{BMI}, \mathrm{HbA}_{1 \mathrm{c}}$, and triglyceride values showed a significant group and time interaction, with higher concentrations in diabetic patients. 
Table 1. Patients' characteristics.

\begin{tabular}{|c|c|c|c|c|}
\hline \multirow{3}{*}{ Parameters } & \multirow{3}{*}{$\begin{array}{c}\text { Total } \\
\text { Mean } \pm \text { SD } \\
\text { Number (\%) }\end{array}$} & \multicolumn{2}{|c|}{ Type 2 Diabetes Mellitus } & \multirow{3}{*}{$p$-Value ${ }^{+}$} \\
\hline & & \multirow{2}{*}{$\begin{array}{c}\text { no }(n=25) \\
\text { Mean } \pm \text { SD } \\
\text { Number }(\%)\end{array}$} & \multirow{2}{*}{$\begin{array}{c}\text { yes }(n=25) \\
\text { Mean } \pm \text { SD } \\
\text { Number }(\%)\end{array}$} & \\
\hline & & & & \\
\hline Female & $40(80)$ & $19(76)$ & $21(84)$ & 0.480 \\
\hline Age (years) & $42.2 \pm 12.5$ & $35.6 \pm 11.9$ & $48.8 \pm 9.3$ & $<0.001$ \\
\hline BMI $\left(\mathrm{kg} / \mathrm{m}^{2}\right)$ & $43.8 \pm 4.3$ & $43.7 \pm 4.9$ & $43.9 \pm 3.7$ & 0.835 \\
\hline \multicolumn{5}{|l|}{ Supplementation } \\
\hline Vitamin D & $8(16)$ & $3(12)$ & $5(20)$ & 0.440 \\
\hline Iron & $1(2)$ & $0(0)$ & $1(4)$ & 0.312 \\
\hline Diuretics use & $12(24)$ & $2(8)$ & $10(40)$ & 0.008 \\
\hline Magnesium (mmol/L) & $0.81 \pm 0.07$ & $0.83 \pm 0.05$ & $0.78 \pm 0.07$ & 0.006 \\
\hline Deficient $(<0.8 \mathrm{mmol} / \mathrm{L})$ & $21(42)$ & $5(20)$ & $16(64)$ & 0.002 \\
\hline Glucose (mg/dL) & $108.7 \pm 36.4$ & $87.6 \pm 8.1$ & $129.9 \pm 41.3$ & $<0.001$ \\
\hline $\mathrm{HbA}_{1 \mathrm{c}}(\%)$ & $6.0 \pm 1.3$ & $5.3 \pm 0.5$ & $6.7 \pm 1.4$ & $<0.001$ \\
\hline OAD use & $9(18)$ & $0(0)$ & $9(36)$ & 0.001 \\
\hline Insulin use & $6(12)$ & $0(0)$ & $6(24)$ & 0.009 \\
\hline Triglycerides (mg/dL) & $155.8 \pm 79.8$ & $164.5 \pm 89.4$ & $147.2 \pm 69.6$ & 0.447 \\
\hline Total cholesterol $(\mathrm{mg} / \mathrm{dL})$ & $198.2 \pm 46.9$ & $197.6 \pm 31.9$ & $198.9 \pm 59$ & 0.920 \\
\hline HDL cholesterol (mg/dL) & $47.3 \pm 12.3$ & $46.3 \pm 10.3$ & $48.2 \pm 14.1$ & 0.578 \\
\hline Cholesterol/HDL ratio & $4.4 \pm 1.2$ & $4.5 \pm 1.3$ & $4.3 \pm 1.2$ & 0.573 \\
\hline LDL cholesterol (mg/dL) & $120.6 \pm 40.3$ & $120 \pm 29.9$ & $121.2 \pm 48.9$ & 0.916 \\
\hline
\end{tabular}

Body Mass Index (BMI), Hemoglobin A1c ( $\left.\mathrm{HbA}_{1 \mathrm{c}}\right)$, Oral antidiabetic drugs (OAD), High density lipoprotein (HDL), Low density lipoprotein (LDL), ${ }^{+} T$-test or Chi ${ }^{2}$-test. A $p$-value in bold denotes a significant difference $(p<0.05)$. 
Table 2. Change in BMI, serum magnesium, glucose, and lipid parameters over time in diabetic and non-diabetic patients.

\begin{tabular}{|c|c|c|c|c|c|c|c|c|c|c|}
\hline \multirow{2}{*}{\multicolumn{2}{|c|}{ Parameters }} & \multirow{2}{*}{$\begin{array}{c}\text { Baseline } \\
\text { Mean } \pm \text { SD }\end{array}$} & \multirow{2}{*}{$p$-Value ${ }^{+}$} & \multirow{2}{*}{$\begin{array}{c}6 \text { Months } \\
\text { Mean } \pm \text { SD }\end{array}$} & \multirow{2}{*}{$p$-Value ${ }^{+}$} & \multirow{2}{*}{$\begin{array}{c}\text { 12 Months } \\
\text { Mean } \pm \text { SD }\end{array}$} & \multirow{2}{*}{$p$-Value ${ }^{+}$} & \multirow{2}{*}{$\begin{array}{l}p \text {-Value } \\
\text { Group }^{+}\end{array}$} & \multirow{2}{*}{$\begin{array}{l}p \text {-Value } \\
\text { Time }^{+}\end{array}$} & \multirow{2}{*}{$\begin{array}{c}p \text {-Value } \\
\text { Group * Time }\end{array}$} \\
\hline & & & & & & & & & & \\
\hline $\operatorname{BMI}\left(\mathrm{kg} / \mathrm{m}^{2}\right)$ & $\begin{array}{l}\text { Non-diabetics } \\
\text { Diabetics }\end{array}$ & $\begin{array}{l}43.7 \pm 4.9 \\
43.9 \pm 3.7\end{array}$ & 0.504 & $\begin{array}{l}32.0 \pm 3.8 \\
32.4 \pm 3.9\end{array}$ & 0.020 & $\begin{array}{l}28.0 \pm 4.2 \\
29.0 \pm 2.5\end{array}$ & 0.001 & 0.004 & $<0.001$ & 0.001 \\
\hline Magnesium (mmol/L) & $\begin{array}{l}\text { Non-diabetics } \\
\text { Diabetics }\end{array}$ & $\begin{array}{l}0.83 \pm 0.05 \\
0.78 \pm 0.07\end{array}$ & 0.006 & $\begin{array}{l}0.84 \pm 0.04 \\
0.78 \pm 0.05\end{array}$ & 0.350 & $\begin{array}{l}0.84 \pm 0.05 \\
0.78 \pm 0.09\end{array}$ & 0.248 & 0.033 & 0.286 & 0.474 \\
\hline Glucose $(\mathrm{mg} / \mathrm{dL})$ & $\begin{array}{l}\text { Non-diabetics } \\
\text { Diabetics }\end{array}$ & $\begin{array}{c}87.6 \pm 8.1 \\
129.9 \pm 41.3\end{array}$ & $<0.001$ & $\begin{array}{c}83.5 \pm 5.5 \\
134.6 \pm 26.5\end{array}$ & 0.029 & $\begin{array}{l}82.2 \pm 5.8 \\
131 \pm 25.7\end{array}$ & 0.019 & $<0.001$ & 0.001 & 0.733 \\
\hline $\mathrm{HbA1c}(\%)$ & $\begin{array}{l}\text { Non-diabetics } \\
\text { Diabetics }\end{array}$ & $\begin{array}{l}5.3 \pm 0.5 \\
6.7 \pm 1.4\end{array}$ & 0.001 & $\begin{array}{l}5.1 \pm 0.3 \\
6.2 \pm 0.7\end{array}$ & 0.006 & $\begin{array}{l}5.1 \pm 0.4 \\
6.4 \pm 0.8\end{array}$ & 0.057 & 0.264 & $<0.001$ & $<0.001$ \\
\hline Triglycerides $(\mathrm{mg} / \mathrm{dL})$ & $\begin{array}{l}\text { Non-diabetics } \\
\text { Diabetics }\end{array}$ & $\begin{array}{l}164.5 \pm 89.4 \\
147.2 \pm 69.6\end{array}$ & 0.072 & $\begin{array}{c}91.3 \pm 29.8 \\
144.2 \pm 30.6\end{array}$ & 0.018 & $\begin{array}{c}85.3 \pm 34.9 \\
104.6 \pm 23.2\end{array}$ & 0.643 & 0.453 & $<0.001$ & 0.007 \\
\hline Total cholesterol $(\mathrm{mg} / \mathrm{dL})$ & $\begin{array}{l}\text { Non-diabetics } \\
\text { Diabetics }\end{array}$ & $\begin{array}{c}197.6 \pm 31.9 \\
198.9 \pm 59\end{array}$ & 0.707 & $\begin{array}{l}165.5 \pm 38.7 \\
170.5 \pm 38.9\end{array}$ & 0.507 & $\begin{array}{l}163.7 \pm 29.6 \\
169.5 \pm 56.1\end{array}$ & 0.474 & 0.547 & $<0.001$ & 0.604 \\
\hline HDL cholesterol $(\mathrm{mg} / \mathrm{dL})$ & $\begin{array}{l}\text { Non-diabetics } \\
\text { Diabetics }\end{array}$ & $\begin{array}{l}46.3 \pm 10.3 \\
48.2 \pm 14.1\end{array}$ & 0.324 & $\begin{array}{c}47.4 \pm 10.2 \\
45.1 \pm 8.9\end{array}$ & 0.995 & $\begin{array}{c}53.8 \pm 9.4 \\
55.1 \pm 11.2\end{array}$ & 0.303 & 0.301 & $<0.001$ & 0.681 \\
\hline Cholesterol/HDL ratio & $\begin{array}{l}\text { Non-diabetics } \\
\text { Diabetics }\end{array}$ & $\begin{array}{l}4.5 \pm 1.3 \\
4.3 \pm 1.2\end{array}$ & 0.272 & $\begin{array}{l}3.6 \pm 0.8 \\
3.7 \pm 0.7\end{array}$ & 0.761 & $\begin{array}{l}3.1 \pm 0.8 \\
3.1 \pm 1.0\end{array}$ & 0.900 & 0.582 & $<0.001$ & 0.726 \\
\hline LDL cholesterol (mg/dL) & $\begin{array}{l}\text { Non-diabetics } \\
\text { Diabetics }\end{array}$ & $\begin{array}{c}120 \pm 29.9 \\
121.2 \pm 48.9\end{array}$ & 0.849 & $\begin{array}{l}99.8 \pm 32.3 \\
96.5 \pm 35.8\end{array}$ & 0.971 & $\begin{array}{l}92.9 \pm 24.9 \\
93.5 \pm 52.1\end{array}$ & 0.735 & 0.924 & $<0.001$ & 0.916 \\
\hline
\end{tabular}

Body Mass Index (BMI), Hemoglobin A1c ( $\left.\mathrm{HbA}_{1 \mathrm{c}}\right)$, High density lipoprotein (HDL), Low density lipoprotein (LDL). ${ }^{+}$Repeated measure analysis of variance and post hoc analysis with Bonferroni correction, adjusted for baseline value, age, and sex. Group * Time means group-by-time interaction. A $p$-value in bold denotes a significant difference $(p<0.05)$. 
Moreover, diabetic patients had an odds ratio of $9.5(95 \% \mathrm{CI}=3.0,29.7 ; p<0.001)$ for Mg deficiency compared with non-diabetics, adjusted for age and sex. In total, Mg deficiency was found in $33 \%$ of the patients at $\mathrm{T} 6$ and $30 \%$ at $\mathrm{T} 12$.

\section{Discussion}

In our study of a cohort of patients with morbid obesity that underwent OAGB surgery, we found significantly lower serum Mg levels in patients with vs. without T2DM at baseline. This finding is in line with other studies confirming the association of low serum Mg and the presence of T2DM $[5,19,20]$. Insulin resistance and deficiency are considered to inhibit the reabsorption of $\mathrm{Mg}$ and accelerate its excretion through the kidneys [28]. Low levels of $\mathrm{Mg}$ in turn further decrease insulin sensitivity and the function of insulin receptors [29]. Overall, our patients with T2DM had an 8.5-fold greater risk of being $\mathrm{Mg}$ deficient compared to patients without T2DM.

Regarding differences in $\mathrm{Mg}$ intake being the reason for low serum levels, a cross-sectional study in a Chinese population reported no significant associations between dietary $\mathrm{Mg}$ intake (evaluated using a semi-quantitative food frequency questionnaire) and T2DM prevalence [20]. Moreover, there was no correlation between dietary $\mathrm{Mg}$ intake and serum concentrations in participants with diabetes. These results are similar to those of other studies emerging from Asia. In contrast, some investigators reported a significantly inverse correlation between dietary $\mathrm{Mg}$ and diabetes [30-32]. This may be due to difference in the degree of insulin resistance in the Asian population in comparison to Western population [33]. Further differences may be found in the dietary patterns, as a study using US nationally representative data found differences among different ethnic groups and their overall $\mathrm{Mg}$ intake [8]. However, this study did not specifically investigate the Asian population in the US due to a lack of data. These results are contradicted by a recent umbrella review of observational and intervention studies indicating that, out of 55 independent outcomes associated with $\mathrm{Mg}$ levels, there was highly suggestive evidence that higher $\mathrm{Mg}$ intake at baseline was associated with lower T2DM incidence [21]. The authors of this umbrella review acknowledge that there is a possible bias in observational studies, since higher $\mathrm{Mg}$ intake might be associated with a healthier lifestyle and dietary patterns. There is also a rather weak evidence that $\mathrm{Mg}$ supplementation is able to significantly improve the results of the $2 \mathrm{~h}$ oral glucose tolerance test in high risk groups for T2DM. Review studies indicated that more randomized controlled trials focusing on different age groups, as well as factors like metabolic control and baseline $\mathrm{Mg}$, are needed in order to provide recommendations on the supplementation of $\mathrm{Mg}$ in patients with diabetes [34].

After OAGB surgery, there was a continuous drop in BMI in all patients, which was significantly greater in nondiabetic subjects at 6 and 12 months follow-up. Differences remained significant after adjusting for age, gender, and baseline values, and showed a significant group-time interaction. However, the drop in BMI was not followed by changes in the serum Mg concentrations. Both groups showed no changes in mean concentrations of serum Mg throughout the study. A 2009 study by Johansson et al. examined 21 patients without diabetes after Roux-en-Y gastric bypass surgery [35]. They reported lower plasma glucose and increased serum Mg levels. Similarly, a 2019 study by Mikalsen Meyer et al. [19] showed that a modest weight loss of about ten kilograms in obese patients with lifestyle interventions already increased serum $\mathrm{Mg}$ levels in obese patients with and without T2DM by around 5\%. After Roux-en-Y gastric bypass surgery, the serum Mg concentrations continued to rise in patients with T2DM and remained stable in non-diabetic patients [19].

Some differences for the controversial findings may arise from surgical techniques, as different techniques are associated with different effects on serum $\mathrm{Mg}$ concentrations. An analysis of patients after Roux-en-Y gastric bypass surgery found that $32 \%$ of patients were Mg deficient. The results showed a mild increase in Mg levels following surgery after two years follow-up and no changes in mean values of serum $\mathrm{Mg}$ concentration at time of the analysis (in mean almost seven years after intervention) [36]. These results are similar as we also found $33 \%$ and $30 \%$ at 6 and 12 months after surgery, respectively. 
This secondary analysis is limited by a rather small sample size that was based on sample size-calculations taking into consideration serum differences of vitamin D concentration. However, as we show significant differences, the sample size calculation can be considered valid. The study is comprised of over $80 \%$ women, which is expected in a patient population undergoing bariatric surgery, but prohibits generalizations to male patients. Moreover, there is no gold standard in determining $\mathrm{Mg}$ status. The strengths of the study include detailed pre- and post-operative data of patients undertaking OAGB, a relatively new surgical procedure that has not been evaluated in regards to $\mathrm{Mg}$ serum concentrations.

\section{Conclusions}

In our patients with obesity, we observed significantly lower serum $\mathrm{Mg}$ levels in patients with vs. those without T2DM. Following bariatric surgery and weight loss, Mg serum concentrations remained stable. Since low Mg levels are associated with hypertension, oxidative stress, and coronary heart disease [9], it is possible that normalized $\mathrm{Mg}$ levels could reduce the risk of comorbidities associated with obesity and T2DM, which, however, needs to be proven.

Author Contributions: Conceptualization, M.W., R.K., B.L., and R.M.; methodology, M.W., B.L., and R.K.; software, M.W.; validation, M.W., R.K., and E.W.; formal analysis, M.W. and E.W.; investigation, M.W., C.K., R.K., K.S., R.M., B.L., and G.P.; resources, G.P. and B.L.; data curation, M.W. and E.W.; writing-original draft preparation, E.W., I.G., and M.W.; writing-review and editing, B.L., R.M., K.S., F.H., G.P., and L.S.; visualization, E.W., I.G., and M.W.; supervision, B.L.; project administration, M.W.; funding acquisition, F.H., B.L. and M.W.

Funding: This research was partly funded by the Austrian Biobanking and BioMolecular resources Research Infrastructure (BBMRI.at), funded by the Austrian Federal Ministry of Science, Research and Economy (BMWFW GZ 10.470/0016-II/3/2013), by the non-profit organization "Special Institute for Preventive Cardiology And Nutrition - SIPCAN" (Salzburg) for personnel costs, and Fresenius Kabi supplied, cost-free, the vitamin $\mathrm{D}_{3}$ and placebo oil, but all had no role in the design and conduct of the study, the collection, analysis, and interpretation of data, in the preparation of the manuscript, or in the review or approval of the manuscript.

Acknowledgments: We would like to thank Miranda Adelfang, Michaela Faustmann, and Hacer Geyik for their support. We would also like to thank Alexandra Kaider for the statistical input and, last but not least, the bariatric patients who participated in this study.

Conflicts of Interest: The authors declare no conflict of interest. The funders had no role in the design of the study; in the collection, analyses, or interpretation of data; in the writing of the manuscript, or in the decision to publish the results.

\section{References}

1. Seo, J.W.; Park, T.J. Magnesium metabolism. Electrolyte Blood Press. 2008, 6, 86-95. [CrossRef] [PubMed]

2. Swaminathan, R. Magnesium metabolism and its disorders. Clin. Biochem. Rev. 2003, 24, 47-66. [PubMed]

3. Veronese, N.; Zanforlini, B.M.; Manzato, E.; Sergi, G. Magnesium and healthy aging. Magnes. Res. 2015, 28, 112-115. [CrossRef] [PubMed]

4. Chutia, H.; Lynrah, K.G. Association of Serum Magnesium Deficiency with Insulin Resistance in Type 2 Diabetes Mellitus. J. Lab. Physicians 2015, 7, 75-78. [CrossRef] [PubMed]

5. Lecube, A.; Baena-Fustegueras, J.A.; Fort, J.M.; Pelegri, D.; Hernandez, C.; Simo, R. Diabetes is the main factor accounting for hypomagnesemia in obese subjects. PLoS ONE 2012, 7, e30599. [CrossRef] [PubMed]

6. Galan, P.; Preziosi, P.; Durlach, V.; Valeix, P.; Ribas, L.; Bouzid, D.; Favier, A.; Hercberg, S. Dietary magnesium intake in a French adult population. Magnes. Res. 1997, 10, 321-328.

7. Moshfegh, A.; Goldman, J.; Ahuja, J.; Rhodes, D.; LaComb, R. What We Eat in America, NHANES 2005-2006: Usual Nutrient Intake from Food and Water Compared to 1997 Dietary Reference Intakes for Vitamin D, Calcium, Phosphorus, and Magnesium. Available online: https://www.ars.usda.gov/ARSUserFiles/80400530/ pdf/0506/usual_nutrient_intake_vitD_ca_phos_mg_2005-06.pdf (accessed on 7 April 2019).

8. Jackson, S.E.; Smith, L.; Grabovac, I.; Haider, S.; Demurtas, J.; Lopez-Sanchez, G.F.; Soysal, P.; Redsell, S.; Isik, A.T.; Yang, L. Ethnic Differences in Magnesium Intake in U.S. Older Adults: Findings from NHANES 2005-2016. Nutrients 2018, 10, 1901. [CrossRef]

9. Guerrero-Romero, F.; Rodriguez-Moran, M. Low serum magnesium levels and metabolic syndrome. Acta Diabetol. 2002, 39, 209-213. [CrossRef] 
10. Nielsen, F.H. Magnesium, inflammation, and obesity in chronic disease. Nutr. Rev. 2010, 68, 333-340. [CrossRef]

11. Barbagallo, M.; Dominguez, L.J. Magnesium metabolism in type 2 diabetes mellitus, metabolic syndrome and insulin resistance. Arch. Biochem. Biophys. 2007, 458, 40-47. [CrossRef]

12. Van Orten-Luiten, A.C.B.; Janse, A.; Verspoor, E.; Brouwer-Brolsma, E.M.; Witkamp, R.F. Drug use is associated with lower plasma magnesium levels in geriatric outpatients; possible clinical relevance. Clin. Nutr. 2018. [CrossRef] [PubMed]

13. James, W.P. WHO recognition of the global obesity epidemic. Int. J. Obes. (2005) 2008, 32, S120-S126. [CrossRef] [PubMed]

14. Klimont, J.; Baldaszti, E. Austrian Health Interview Survey. Oesterreichische Gesundheitsbefragung 2014. Hauptergebnisse des Austrian Health Interview Survey (AT-HIS) und Medizinische Dokumentation; Austrian Statistics Agency: Vienna, Austria, 2015.

15. Blair, S.N.; Horton, E.; Leon, A.S.; Lee, I.M.; Drinkwater, B.L.; Dishman, R.K.; Mackey, M.; Kienholz, M.L. Physical activity, nutrition, and chronic disease. Med. Sci. Sports Exerc. 1996, 28, 335-349.

16. Magkos, F.; Fraterrigo, G.; Yoshino, J.; Luecking, C.; Kirbach, K.; Kelly, S.C.; de Las Fuentes, L.; He, S.; Okunade, A.L.; Patterson, B.W.; et al. Effects of Moderate and Subsequent Progressive Weight Loss on Metabolic Function and Adipose Tissue Biology in Humans with Obesity. Cell Metab. 2016, 23, 591-601. [CrossRef] [PubMed]

17. Buchwald, H.; Oien, D.M. Metabolic/bariatric surgery Worldwide 2008. Obes. Surg. 2009, 19, $1605-1611$. [CrossRef] [PubMed]

18. Himpens, J.; Ramons, A.; Welbourn, R.; Dixon, J.; Kinsman, R.; Walton, P. Fourth IFSO Global Registry Report; Dendrite Clinical Systems Ltd.: Reading, UK, 2018.

19. Mikalsen, S.M.; Bjorke-Monsen, A.L.; Whist, J.E.; Aaseth, J. Improved Magnesium Levels in Morbidly Obese Diabetic and Non-diabetic Patients After Modest Weight Loss. Biol. Trace Elem. Res. 2019, 188, 45-51. [CrossRef]

20. Wei, J.; Zeng, C.; Li, X.X.; Gong, Q.Y.; Lei, G.H.; Yang, T.B. Association among dietary magnesium, serum magnesium, and diabetes: A cross-sectional study in middle-aged and older adults. J. Health Popul. Nutr. 2016, 35, 33. [CrossRef]

21. Veronese, N.; Demurtas, J.; Pesolillo, G.; Celotto, S.; Barnini, T.; Calusi, G.; Caruso, M.G.; Notarnicola, M.; Reddavide, R.; Stubbs, B.; et al. Magnesium and health outcomes: An umbrella review of systematic reviews and meta-analyses of observational and intervention studies. Eur. J. Nutr. 2019. [CrossRef]

22. Luger, M.; Kruschitz, R.; Kienbacher, C.; Traussnigg, S.; Langer, F.B.; Prager, G.; Schindler, K.; Kallay, E.; Hoppichler, F.; Trauner, M.; et al. Vitamin D3 Loading Is Superior to Conventional Supplementation After Weight Loss Surgery in Vitamin D-Deficient Morbidly Obese Patients: A Double-Blind Randomized Placebo-Controlled Trial. Obes. Surg. 2017, 27, 1196-1207. [CrossRef]

23. Luger, M.; Kruschitz, R.; Marculescu, R.; Haslacher, H.; Hoppichler, F.; Kallay, E.; Kienbacher, C.; Klammer, C.; Kral, M.; Langer, F.; et al. The link between obesity and vitamin D in bariatric patients with omega-loop gastric bypass surgery-A vitamin D supplementation trial to compare the efficacy of postoperative cholecalciferol loading (LOAD): Study protocol for a randomized controlled trial. Trials 2015, 16, 328. [CrossRef]

24. Rutledge, R. The mini-gastric bypass: Experience with the first 1,274 cases. Obes. Surg. 2001, 11, $276-280$. [CrossRef] [PubMed]

25. Schulz, K.F.; Altman, D.G.; Moher, D.; Group, C. CONSORT 2010 Statement: Updated guidelines for reporting parallel group randomised trials. Trials 2010, 11, 32. [CrossRef] [PubMed]

26. Dale, O.; Salo, M. The Helsinki Declaration, research guidelines and regulations: Present and future editorial aspects. Acta Anaesthesiol. Scand. 1996, 40, 771-772. [CrossRef] [PubMed]

27. Zhang, S.; Paul, J.; Nantha-Aree, M.; Buckley, N.; Shahzad, U.; Cheng, J.; DeBeer, J.; Winemaker, M.; Wismer, D.; Punthakee, D.; et al. Empirical comparison of four baseline covariate adjustment methods in analysis of continuous outcomes in randomized controlled trials. Clin. Epidemiol. 2014, 6, 227-235. [CrossRef] [PubMed]

28. Sales, C.H.; Pedrosa, L. Magnesium and diabetes mellitus: Their relation. Clin. Nutr. 2006, 25, 554-562. [CrossRef] [PubMed] 
29. Barbagallo, M.; Dominguez, L.J.; Galioto, A.; Ferlisi, A.; Cani, C.; Malfa, L.; Pineo, A.; Busardo, A.; Paolisso, G. Role of magnesium in insulin action, diabetes and cardio-metabolic syndrome X. Mol. Asp. Med. 2003, 24, 39-52. [CrossRef]

30. Hata, A.; Doi, Y.; Ninomiya, T.; Mukai, N.; Hirakawa, Y.; Hata, J.; Ozawa, M.; Uchida, K.; Shirota, T.; Kitazono, T.; et al. Magnesium intake decreases Type 2 diabetes risk through the improvement of insulin resistance and inflammation: The Hisayama Study. Diabet. Med. 2013, 30, 1487-1494. [CrossRef]

31. Hruby, A.; Meigs, J.B.; O’Donnell, C.J.; Jacques, P.F.; McKeown, N.M. Higher magnesium intake reduces risk of impaired glucose and insulin metabolism and progression from prediabetes to diabetes in middle-aged americans. Diabetes Care 2014, 37, 419-427. [CrossRef] [PubMed]

32. Weng, L.C.; Lee, N.J.; Yeh, W.T.; Ho, L.T.; Pan, W.H. Lower intake of magnesium and dietary fiber increases the incidence of type 2 diabetes in Taiwanese. J. Formos. Med. Assoc. 2012, 111, 651-659. [CrossRef]

33. Nanri, A.; Mizoue, T.; Noda, M.; Takahashi, Y.; Kirii, K.; Inoue, M.; Tsugane, S. Magnesium intake and type II diabetes in Japanese men and women: The Japan Public Health Center-based Prospective Study. Eur. J. Clin. Nutr. 2010, 64, 1244-1247. [CrossRef]

34. Barbagallo, M.; Dominguez, L.J. Magnesium and type 2 diabetes. World J. Diabetes 2015, 6, $1152-1157$. [CrossRef] [PubMed]

35. Johansson, H.E.; Zethelius, B.; Ohrvall, M.; Sundbom, M.; Haenni, A. Serum magnesium status after gastric bypass surgery in obesity. Obes. Surg. 2009, 19, 1250-1255. [CrossRef] [PubMed]

36. Dalcanale, L.; Oliveira, C.P.; Faintuch, J.; Nogueira, M.A.; Rondo, P.; Lima, V.M.; Mendonca, S.; Pajecki, D.; Mancini, M.; Carrilho, F.J. Long-term nutritional outcome after gastric bypass. Obes. Surg. 2010, 20, 181-187. [CrossRef] [PubMed]

(C) 2019 by the authors. Licensee MDPI, Basel, Switzerland. This article is an open access article distributed under the terms and conditions of the Creative Commons Attribution (CC BY) license (http://creativecommons.org/licenses/by/4.0/). 